\title{
KANDUNGAN GIZI ASI (AIR SUSU IBU) PADA BERBAGAI SUHU DAN LAMA PENYIMPANAN
}

\section{BREAST MILK NUTRIENT CONTENT IN DIFFERENT STORAGE TEMPERATURE AND DURATION}

\author{
${ }^{1}$ Puspito Arum, ${ }^{2}$ Agatha Widiyawati \\ ${ }^{1,2}$ Progam Studi Gizi Klinik Jurusan Kesehatan Politeknik Negeri Jember \\ Jalan Mastrip Kotak Pos 164, Jember, \\ puspito_arum@yahoo.com
}

\begin{abstract}
Abstrak
ASI merupakan satu jenis makanan yang mencukupi seluruh unsur kebutuhan bayi baik karena ASI mengandung zat gizi, hormon, faktor kekebalan tubuh, anti alergi, dan anti inflamasi. ASI mengandung hampir 200 unsur zat makanan. ASI perah dapat disimpan mulai dari beberapa jam hingga beberapa bulan, tergantung dari suhu penempatannya. Suhu dan lama waktu penyimpanan akan mempengaruhi kandungan zat gizi yang ada pada ASI. Tujuan penelitian ini adalah untuk menganalisis perbedaan kandungan gizi ASI pada berbagai suhu dan lama penyimpanan. Variabel dalam penelitian ini adalah zat gizi makro yang terkandung dalam ASI, meliputi karbohidrat, lemak dan protein. Metode analisis protein menggunakan metode Kjedahk, metode analisis lemak menggunakan pendekatan metode Babcock dan metode analisis karbohidrat menggunakan metode indeks bias refraktometer. Kandungan protein pada sampel ASI berkisar antara 0,7940 - 0,8439 \%, kandungan lemak pada sampel ASI berkisar antara 1,5 - 2,7 \%, Kkandungan karbohidrat pada sampel ASI berkisar antara 9-9,23\%. Terjadi kenaikan kandungan protein ASI pada berbagai perlakuan suhu dan lama penyimpanan. Terjadi kenaikan kandungan lemak ASI pada berbagai perlakuan suhu dan lama penyimpanan. Terjadi penurunan kandungan karbohidrat ASI pada berbagai perlakuan suhu dan lama penyimpaan.
\end{abstract}

\begin{abstract}
Breast milk is the kind of food that provide all elements of the baby's needs well, because breast milk contains nutrients, hormones, immune factors, anti-allergic and anti-inflammatory. Breast milk contains nearly 200 elements of a food substance. Breastmilk can be stored ranging from several hours to several months, depending on the temperature of the storage. The temperature and duration will affect nutrients content in milk. The purpose of this study was to analyze the differences nutrient content of breast milk in a wide range of temperature and storage duration. The variable in this study is the macro-nutrients contained in breast milk, including carbohydrates, fats and proteins. Methods of protein analysis using Kjedahl methods, methods of fat analysis using approach Babcock methode and methode of carbohydrate analysis using the refractive index refractometer. The protein content of breast milk samples ranged from 0.7940 to $0.8439 \%$, the fat content in the breast milk samples ranged from 1.5 to $2.7 \%$, Carbohydrates in breast milk samples ranged from 9 to $9.23 \%$. An increase in the protein content of breast milk in a variety of temperature treatment and storage time. An increase in the fat content of breast milk in a variety of temperature treatment and storage time. There was a decrease in carbohydrate content of breast milk at various temperatures and long treatment penyimpaan.
\end{abstract}

Key words : ASI, Babcock, Karbohidrat, Lemak, Protein 


\section{PENDAHULUAN}

Menyusui adalah proses pemberian ASI pada bayi oleh ibu dan merupakan kondisi yang alamiah yang dialami oleh wanita setelah melahirkan (Krisnatuti \& Hastoro, 2000). Air susu ibu (ASI) adalah sumber gizi dan makanan paling aman dan idel bagi bayi usia 0-6 bulan (Adriani, 2012). ASI merupakan satu jenis makanan yang mencukupi seluruh unsur kebutuhan bayi baik karena ASI mengandung zat gizi, hormon, faktor kekebalan tubuh, anti alergi, dan anti inflamasi. ASI mengandung hampir 200 unsur zat makanan (Hubertin, 2003).

ASI perah dapat disimpan mulai dari beberapa jam hingga beberapa bulan, tergantung dari suhu penempatannya. Suhu dan lama waktu penyimpanan akan mempengaruhi kandungan zat gizi yang ada pada ASI. Suhu ideal penyimpanan ASI dalam freezer adalah $-20--15{ }^{\circ} \mathrm{C}$, namun pada kenyataannya suhu freezer lemari pendingin yang ada di rumah belum tentu menunjukkan suhu tersebut. Kondisi seperti ini akan menimbulkan kemungkinan perubahan nilai zat gizi yang terkandung dalam ASI. Tujuan penelitian ini adalah untuk menganalisis perbedaan kandungan gizi ASI pada berbagai suhu dan lama penyimpanan

\section{METODOLOGI}

Sampel penelitian adalah ASI yang diambil dari payudara ibu menyusui dengan cara dipompa. ASI yang digunakan berupa ASI yang baru saja diambil dan ASI yang disimpan pada suhu dan dan lama penyimpanan tertentu, yaitu suhu ruang selama 0 menit dan 3 jam, disimpan dalam freezer selama 3 hari, 1 minggu dan 2 minggu.

Variabel dalam penelitian ini adalah zat gizi makro yang terkandung dalam ASI, meliputi karbohidrat, lemak dan protein. Semua variabel memiliki skala ukur rasio.

Metode analisis protein menggunakan metode Kjedahk, metode analisis lemak menggunakan pendekatan metode Babcock dan metode analisis karbohidrat menggunakan metode indeks bias refraktometer.

Analisis deskriptif digunakan untuk menjelaskan karakterikstik kandungan zat gizi pada masing-masing sampel ASI pada berbagai suhu danlama penyimpan.. Analisis inferensial digunakan untuk menganaliais perbedaan kandungan gizi antar sampel ASI pada berbagai suhu dan lama.penyimpanan.

\section{HASIL DAN PEMBAHASAN}

Lima belas sampel ASI yang terkumpul dibagi menjadi berdasarkan perlakuan yang diamati, yaitu ASI perah (ASIP) segar, ASIP segar yang didiamkan pada suhu ruang selama 3 jam, ASIP yang disimpan dalam freezer selama 3 hari, ASIP yang disimpan dalam freezer selama 1 minggu dan ASIP yang disimpan dalam freezer selama 2 minggu. Penelitian ini ingin mengetahui pengaruh penyimpanan beku di freezer lemari pendingin rumahan pada lama waktu tertentu terhadap kandungan gizi ASIP. Suhu penyimpanan dalam freezer tidak mengacu pada suhu tertentu dengan alasan pada praktik keseharian pada umumnya masyarakat tidak memperhatikan suhu lemari pendingin.

Air Susu Ibu (ASI) adalah suatu emulsi lemak dalam larutan protein, laktosa dan garam-garam organik yang disekresikan oleh kelenjar payudara ibu, dan berguna sebagai makanan bayi (Kristiyansari, 2009). ASI merupakan satu jenis makanan yang mencukupi seluruh unsur kebutuhan bayi baik karena ASI mengandung zat gizi, hormon, faktor kekebalan tubuh, anti alergi, dan anti inflamasi. ASI mengandung hampir 200 unsur zat makanan (Hubertin, 2003). Keseimbangan zatzat gizi dalam ASI berada pada komposisi terbaik dan air susunya memiliki bentuk paling ideal bagi tubuh bayi, khususnya bayi usia 0-6 bulan. ASI juga sangat kaya akan sari-sari makanan yang mempercepat pertumbuhan sel-sel otak dan perkembangan sistem saraf bayi (Yahya, 2007).

Pengiriman lima belas sampel ASIP ke laboratorium tidak dilakukan secara bersamaan, namun analisis kandungan gizi oleh laboratorium dilakukan secara bersamaan. Selama menunggu waktu analisis, sampel ASIP disimpan di laboratorium pada pendingin dengan suhu terkontrol $-80{ }^{\circ} \mathrm{C}$. Penyimpanan pada suhu $-80{ }^{\circ} \mathrm{C}$ merupakan suhu penyimpanan yang dapat meminimalisir kerusakan dan perubahan kandungan zat gizi pada susu (Ogundele, 2000)

Tabel 1. Kandungan gizi ASI pada berbagai tempat penyimpanan dan lama penyimpanan

\begin{tabular}{|c|c|c|c|c|c|}
\hline $\begin{array}{c}\text { No } \\
\text {. }\end{array}$ & $\begin{array}{c}\text { Tempat } \\
\text { penyim } \\
\text { panan }\end{array}$ & $\begin{array}{c}\text { Lama } \\
\text { penyim } \\
\text { panan }\end{array}$ & $\begin{array}{c}\text { Rerata } \\
\text { kandu } \\
\text { ngan } \\
\text { protei } \\
\text { n }(\%)\end{array}$ & $\begin{array}{c}\text { Rerata } \\
\text { kandu } \\
\text { ngan } \\
\text { Lema } \\
\text { k }(\%)\end{array}$ & $\begin{array}{c}\text { Rerat } \\
\text { a } \\
\text { kand } \\
\text { unga } \\
\text { n } \\
\text { Karb } \\
\text { ohidr } \\
\text { at } \\
(\%)\end{array}$ \\
\hline 1 & $\begin{array}{l}\text { Ruanga } \\
n\end{array}$ & 0 menit & $\begin{array}{c}0,7940 \\
\pm \\
0.0194\end{array}$ & $\begin{array}{l}2,1 \pm \\
0.089\end{array}$ & $\begin{array}{c}9,23 \\
\pm \\
0.057\end{array}$ \\
\hline
\end{tabular}




\begin{tabular}{|c|c|c|c|c|c|}
\hline 2 & $\begin{array}{l}\text { Ruanga } \\
\mathrm{n}\end{array}$ & 3 jam & $\begin{array}{c}0,7803 \\
\pm \\
0.0252\end{array}$ & $\begin{array}{l}2,4 \pm \\
0.421\end{array}$ & $\begin{array}{c}9,17 \\
\pm \\
0.057\end{array}$ \\
\hline 3 & Freezer & 3 hari & $\begin{array}{c}0,7985 \\
\pm \\
0.0131\end{array}$ & $\begin{array}{l}2,3 \pm \\
0.697\end{array}$ & $\begin{array}{c}9,13 \\
\pm \\
0.057\end{array}$ \\
\hline 4 & Freezer & $\begin{array}{l}1 \\
\text { minggu }\end{array}$ & $\begin{array}{c}0,8438 \\
\pm \\
0.0509\end{array}$ & $\begin{array}{l}1,5 \pm \\
0.392\end{array}$ & $\begin{array}{c}9,00 \\
\pm \\
0.057\end{array}$ \\
\hline 5 & Freezer & $\begin{array}{l}1 \\
\text { minggu }\end{array}$ & $\begin{array}{c}0,8029 \\
\pm \\
0.0320\end{array}$ & $\begin{array}{l}2,7 \pm \\
0.670\end{array}$ & $\begin{array}{c}9,03 \\
\pm \\
0.057\end{array}$ \\
\hline
\end{tabular}

Kandungan protein pada sampel ASI berkisar antara $0,7940-0,8439 \%$ atau setara dengan $8-$ 8,5 gram. Nilai ini tidak jauh berbeda bila dibandingkan dengan rerata nilai estimasi konsentrasi zat gizi yang terdapat pada ASI, yaitu 9 g / liter ASI (Raaij, 2016). Kandungan protein cenderung meningkat seiring dengan peningkatan lama waktu penyimpanan. Uji beda menunjukkan terdapat perbedaan nilai kandungan protein antar perlakuan $(\mathrm{p}=0,047)$ Perbedaan kandungan protein, secara statistik, terlihat antara perlakuan ke-2 pada perlakuan ke-4, yaitu pada ASIP yang disimpan pada suhu ruang selama 3 jam dengan ASIP yang disimpan di freezer selama 1 minggu. Keadaan ini bisa berhubungan dengan kondisi kehilangan air selama proses pembekuan dan pencairan kembali (Chang, et.al 2012). Proses pencairan kembali pada ASIP dapat menyebabkan penggumpalan molekul protein sehingga menyebabkan ni;ai protein yang bervariasi (Abranches, et.al, 2014)

Tabel 2 . Nilai signifikansi perbedaan kandungan gizi antar perlakuan

\begin{tabular}{cc}
\hline Zat Gizi & p \\
\hline Protein & 0.047 \\
Lemak & 0.106 \\
Karbohidrat & 0.001 \\
\hline
\end{tabular}

Kandungan lemak pada sampel ASI berkisar antara 1,5-2,7\% atau setara dengan 16-28 gram. Nilai ini berbeda bila dibandingkan dengan rerata nilai estimasi konsentrasi zat gizi yang terdapat pada ASI, yaitu 37 - 40 g / liter ASI (Raaij, 2016). Kandungan lemak cenderung meningkat seiring dengan peningkatan lama waktu penyimpanan. Uji beda menunjukkan tidak terdapat perbedaan nilai kandungan lemak antar perlakuan $(\mathrm{p}=0,106)$. Kandungan lemak ASI seolah-olah mengalami peningkatan kandungan lemak dikarenakan adanya aktifitas lipolisis. Aktifitas lipolisis terjadi lebih cepat pada suhu $25{ }^{\circ} \mathrm{C}$ atau suhu ruang dibanding pada suhu $15{ }^{\circ} \mathrm{C}$ atau lebih rendah (Hamosh, et.al, 1996). Perlakuan ke-1 dan ke-2 ASIP masih diletakkan pada suhu ruang, sedangkan pada perlakuan ke-3 sampai ke-5 ASI langsung disimpan dalam freezer, sehingga proses lipolisisnya terhenti.

Kandungan karbohidrat pada sampel ASI berkisar antara 9-9,23\% atau setara dengan 90 - 92 gram. Nilai ini berbeda bila dibandingkan dengan rerata nilai estimasi konsentrasi zat gizi yang terdapat pada ASI, yaitu $67 \mathrm{~g} /$ liter ASI (Raaij, 2016). Kandungan karbohidrat cenderung turun seiring dengan peningkatan lama waktu penyimpanan. Uji beda menunjukkan terdapat perbedaan nilai kandungan karbohidrat antar perlakuan ( $\mathrm{p}=$ 0,001). Perbedaan karbohidrat, secara statistik, terlihat pada perlakuan ke-1 dengan perlakuan ke-4 dan ke-5, yaitu ASIP yang baru keluar dari payudara ibu dengan ASIP yang disimpan dalam freezer selama 1 minggu dan 2 minggu, serta terlihat pada perlakuan ke-2 dengan perlakuan ke4, yaitu pada ASIP yang disimpan pada suhu ruang selama 3 jam dengan ASIP yang disimpan di freezer selama 1 minggu. Lama penyimpanan ASIP berpengaruh pada pertumbuhan bakteri. Bakteri mampu mengurai karbohidrat yang ada pada susu, sehingga menyebabkan kandungan karbohidrat menjadi rendah (Hamosh, et.al 1996)

Tabel 3 .Nilai perbedaan antar perlakuan

\begin{tabular}{|c|c|c|c|}
\hline Zat Gizi & Kelompok & Perlakuan & $\mathbf{p}$ \\
\hline \multirow[t]{10}{*}{ Protein } & 1 & 2 & 0.935 \\
\hline & & 3 & 0.999 \\
\hline & & 4 & 0.110 \\
\hline & & 5 & 0.986 \\
\hline & 2 & 3 & 0.842 \\
\hline & & 4 & 0.034 \\
\hline & & 5 & 0.716 \\
\hline & 3 & 4 & 0.159 \\
\hline & & 5 & 0.999 \\
\hline & 4 & 5 & 0.228 \\
\hline \multirow[t]{9}{*}{ Lemak } & 1 & 2 & 0.933 \\
\hline & & 3 & 0.974 \\
\hline & & 4 & 0.610 \\
\hline & & 5 & 0.550 \\
\hline & 2 & 3 & 1.000 \\
\hline & & 4 & 0.245 \\
\hline & & 5 & 0.928 \\
\hline & 3 & 4 & 0.314 \\
\hline & & 5 & 0.861 \\
\hline
\end{tabular}




\begin{tabular}{llll}
\hline & 4 & 5 & 0.076 \\
Karbohidrat & 1 & 2 & 0.539 \\
& & 3 & 0.200 \\
& 4 & 0.002 \\
& & 5 & 0.005 \\
& & 3 & 0.928 \\
& 4 & 0.018 \\
& 5 & 0.061 \\
& & 4 & 0.061 \\
& & 5 & 0.200 \\
& & 5 & 0.928 \\
\hline
\end{tabular}

Kandungan zat gizi pada ASI berbeda pada tiap-tiap individu. Laktasi merupakan periode ketika seorang individu sangat bergantung pada asupan zat gizi (Andriani, 2012). Faktor gizi sangat berperan dalam menentukan komposisi zat gizi dalam ASI. Komposisi zat gizi dalam ASI sangat bergantung pada asupan makan ibu (Erick, 2012).

\section{KESIMPULAN}

Terjadi kenaikan kandungan protein ASI pada berbagai perlakuan suhu dan lama penyimpanan. Terjadi kenaikan kandungan lemak ASI pada berbagai perlakuan suhu dan lama penyimpanan. Terjadi penurunan kandungan karbohidrat ASI pada berbagai perlakuan suhu dan lama penyimpaan. Pemberian ASIP merupakan praktik yang sudah umum dilakukan oleh ibu yang tidak dapat menyusui bayinya secara langsung dari payudara, khususnya dengan alasan bekerja.

Penelitian selanjutnya diharapkan dapat melengkapi dengan meneliti zat gizi lain, khususnya zat gizi mikro yang rentan terhadap perubahan suhu dan lama penyimpanan. Penyimpanan ASIP sebaiknya memperhatikan suhu dan lama penyimpanan.

\section{UCAPAN TERIMA KASIH}

Terimakasih disampaikan kepada semua pihak yang telah mendukung terlaksananya kegiatan ini, khususnya ibu yang sudah bersedia memberikan ASI. Kegiatan ini didanai oleh DIPA Politeknik Negeri Jember Nomor : SP DIPA042.01.2.401005/2016 Tanggal 7 Desember 2015

\section{DAFTAR PUSTAKA}

Abranches, AD, Soares, FVM, Saint-Claire, GJ, Moreira, MEL. 2014. Freezeng and thawing effect on fat, protein, and lactose level of human natural milk administered by gavage and continuous infusion. J Pediats (Rio J), 90(4):384-388
Academy of Breastfeeding Medicine. 2004) Clinical Protocol Number \#8: Human Milk Storage Information for Home Use for Healthy Full Term Infants . Princeton Junction, New Jersey: Academy of Breastfeeding Medicine

Andriani, M. Wirjatmadi, B. 2012. Peran gizi dalam siklus kehidupan. Jakarta : Kencana Prenada Media Group

Badriul, dkk. 2008. Bedah ASI. Jakarta: Balai Penerbit FKUI

Chang, YC, Chen, CH, Lin, MC. 2012. The macronutrient in human milk change after storage in various container. Pediatric and Neonatology, 53:205-209

Erick, M. 2012. Nutrition in pregnancy and lactation, in Krause'e Foof anh the nutrition care process 13th edition. Elseiver

Hamosh, M, Ellis, LA, Pollock, DR, Hamosh, p. Breastfeeding and the working mother: effct of time and temperature of short term storage on proteolysis, lipolysis, and bacterial growth in milk. Pediatrics, 97:492-498

Kristiyansari, W., 2009. ASI:Menyusui dan Sadari. Yogyakarta: Nuha Medika.

Maryunani, Anik. 2012. Inisiasi Menyusu Dini, ASI Eksklusif Dan Manajemen Laktasi. Jakarta : CV. Trans Info Media.

Ogundele MO. 2000. Techniques for the storage of human breast milk : Implication for antimicrobial functions and safety of stored milk. Eur j Pediatr. 159:793-797

Pertiwi, P. 2012. Gambaran faktor-faktor yang mempengaruhi pemberian ASI eksklusif di kelurahan kunciran indah Tanggerang. Skripsi. Universitas Indonesia

Raaij, JMA, Groot, LCPGM. 2016. Kehamilan dan laktasi, dalam Metabolisme zat gizi. Jakarta : EGC

Roesli, Utami. 2010. Mengenal ASI Eksklusif. Jakarta. Pustaka Pembangunan Swadaya Nusantara

Soetjiningsih. 1997. ASI : Petunjuk Untuk Tenaga Kesehatan. Jakarta. ECG

Sri purwanti, Hubertin. 2003 Konsep penerapan ASI eksklusif: buku saku untukbidan. Jakarta: EGC

Yahya. 2005. Cairan Ajaib Air Susu Ibu, Jakarta.Medika. 